\title{
molecules
}

ISSN 1420-3049

www.mdpi.com/journal/molecules

Article

\section{Chamaejasmine Arrests Cell Cycle, Induces Apoptosis and Inhibits Nuclear NF-kB Translocation in the Human Breast Cancer Cell Line MDA-MB-231}

Tingting Zhang ${ }^{1, \dagger}$, Hongyang Yu ${ }^{2, \dagger}$, Guanglu Dong ${ }^{2}$, Li Cai ${ }^{1, *}$ and Yuxian Bai ${ }^{1, *}$

1 Oncology Department of Internal Medicine, the Third Affiliated Hospital of Harbin Medical University, Harbin 150040, China; E-Mail: zhangting2002@sina.com

2 Department of Radiation Oncology, the Second Affiliated Hospital of Harbin Medical University, Harbin 150086, China; E-Mails: 18704665791@139.com (H.Y.); dg164@163.com (G.D.)

$\dagger$ These authors contributed equally to this work.

* Authors to whom correspondence should be addressed; E-Mails: caiwenxin76@yahoo.com.cn (L.C.); bai_yuxian@126.com (Y.B.); Tel.: +86-451-8629-8735 (L.C.); Fax: +86-451-8629-8689 (L.C.).

Received: 19 November 2012; in revised form: 4 January 2013 / Accepted: 5 January 2013 /

Published: 11 January 2013

\begin{abstract}
In this study, the anticancer activity of chamaejasmine was characterized in the human breast cancer cell line, MDA-MB-231. Cell viability and cell cycle distribution were determined by MTT assay and flow cytometry, respectively. Western blotting was performed to determine changes in levels of various proteins. Results showed that treatment with chamaejasmine $(4-16 \mu \mathrm{M})$ inhibited cell proliferation, which correlated with G2/M phase arrest and apoptosis in MDA-MB-231 cells. Chamaejasmine treatment of MDA-MB-231 cells resulted in induction of WAF1/p21 and KIP1/p27, decrease in cyclins A and cyclins B1. Cyclin-dependent kinase (cdk) 2 and cdc2 was also decreased after chamaejasmine treatment. Moreover, inhibition of nuclear translocation, phosphorylation of NF- $\kappa \mathrm{B}$, activation of IKK $\alpha$ and IKK $\beta$, inhibition of phosphorylation and degradation of I $\mathrm{B} \alpha$ were also detected in this work. Our findings suggested that chamaejasmine could be explored as a preventive and perhaps as a chemotherapeutic agent in the management of breast cancer.
\end{abstract}

Keywords: chamaejasmine; MDA-MB-231; MTT; flow cytometry; western blotting 


\section{Introduction}

Breast cancer, a major malignant tumor threatens women's health, and is the second leading cause of women's death [1]. It threatens women in all races [2]. Surgery and chemotherapy or/and radiation are usually used for breast cancer treatment [3,4]. Therapies such as paclitaxel (taxol) are commonly used to treat breast cancer, but these drugs usually have frightening toxicity to normal cells [5]. Therefore, an understanding of the molecular mechanisms of more effective and less harmful potential medicines is sorely needed.

Cell cycle control is a highly regulated process in which cyclin-dependent kinases, cyclin-dependent kinase inhibitors, and cyclins play essential roles [6]. The regulation of the expression and function of the cell cycle machinery proteins (including cyclins, CDKs, CKIs, p21, and p27) has provided an important mechanism for inhibiting cell growth [7].

Apoptosis, a form of programmed cell death, occurs through activation of the cell's intrinsic suicide machinery [8]. It is an important hallmark of anticancer drug-induced cell death [9-11]. Apoptosis is characterized by condensation of cytoplasm and chromatin, DNA fragmentation, and cell fragmentation into apoptotic bodies, followed by removal and degradation of the dying cells by phagocytosis. It has been considered as the major form of cell death in various physiological events [12,13].

Recently, numerous medical plants have served as sources of anticancer pharmaceuticals, and more than $60 \%$ of current anticancer drugs such as vinblastine, topotecan, etoposide, and paclitaxel were originally plant-derived compounds [14,15]. Stellerachamaejasme L. (Thymealaeaceae) is widely distributed in the northwest and southwest parts of China. It has been reported that the roots of Stellerachamaejasme L., could be used as a pesticide to kill bugs, flies and maggots, and could also control pests on crops, and pastures [16,17]. Moreover, the methanol extract of Stellerachamaejasme L. showed significant antitumor activities [18]. Chemical constituent investigations indicated Stellerachamaejasme L. is rich in biflavonones, which have been considered as being responsible for the beneficial effects of Stellerachamaejasme L. on human health [19]. Chamaejasmine (Figure 1), a natural biflavanone, was one of the major biflavanones obtained from Stellerachamaejasme L. [20]. As far as we know, the anticancer activity of chamaejasmine against MDA-MB-231 has not been elucidated until now.

Figure 1. Chemical structure of chamaejasmine and apigenin.
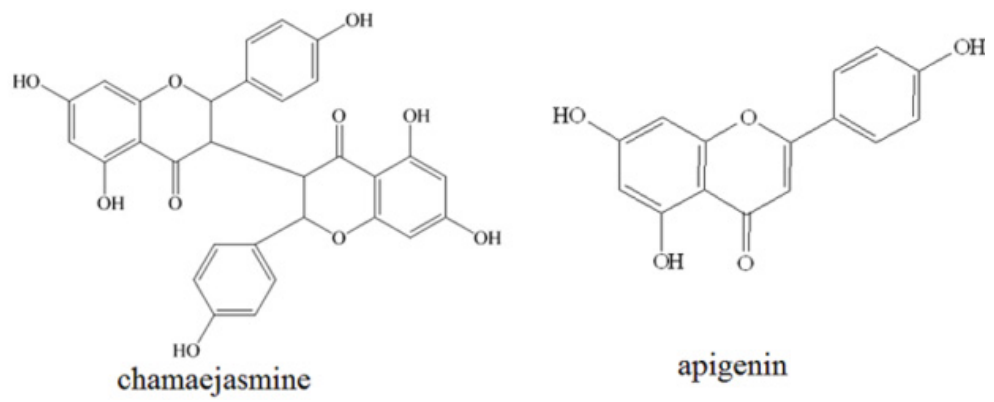

In the present study, the antiproliferation activity of chamaejasmine against three human breast cancer cell lines (HCC1937, MDA-MB-453 and MDA-MB-231) was evaluated by MTT assay first. The cell cycle arrest and apoptosis was further studied by flow cytometry. The expression of p21, p27, 
cdk2, cdc2, cyclin A and cyclin B1 was further detected by western blotting in MDA-MB-231 cells. Measurements of Bcl-2, Bax, caspase- 3 and capspase- 8 were used to assess apoptosis. Finally, we determined the chemotherapeutic potential of chamaejasmine on phosphorylation and activation of $\mathrm{NF}-\kappa \mathrm{B}$ in MDA-MB-231 cells.

\section{Results}

\subsection{Heading Cytotoxicity Assays}

The cytotoxicity of chamaejasmine was evaluated on three human breast cancer cell lines (HCC1937, MDA-MB-453 and MDA-MB-231) using MTT assays. Apigenin was used as positive control. The results were listed in Table 1. Chamaejasmine exhibited stronger inhibition against all three cancer cell lines than apigenin. Among all of them, chamaejasmine showed more notable cytotoxicity against MDA-MB-231 than $\mathrm{HCC} 1937$ and MDA-MB-453, with $\mathrm{IC}_{50}$ values of 4.72, 13.44 and $5.66 \mu \mathrm{M}$, respectively.

Table 1. Inhibition concentrations $50 \% \quad\left(\mathrm{IC}_{50}\right)$ values for chamaejasmine towards HCC1937, MDA-MB-453 and MDA-MB-231 cells determined by MTT assay. * Statistically different from positive control (apigenin, $p<0.05$ ).

\begin{tabular}{ccc}
\hline \multirow{2}{*}{ Cell lines } & \multicolumn{2}{c}{$\mathbf{I C}_{\mathbf{5 0}}(\boldsymbol{\mu M})$} \\
\cline { 2 - 3 } & Chamaejasmine & Apigenin \\
\hline HCC1937 & $13.44^{*}$ & 35.97 \\
MDA-MB-453 & $5.66^{*}$ & 31.12 \\
MDA-MB-231 & $4.72^{*}$ & 21.77 \\
\hline
\end{tabular}

\subsection{G2-M Phase Cell Cycle Arrest and Apoptosis by Chamaejasmine in MDA-MB-231 Cells}

To determine whether chamaejasmine-induced apoptosis was related to arrest of cell cycle progression, flow cytometry was used to quantitate the cell cycle distribution in MDA-MB-231 cells under treatment with different chamaejasmine concentrations $(4-16 \mu \mathrm{M})$. As shown in the concentration kinetic measurements (Figure 2), exposure to 4-16 $\mu \mathrm{M}$ chamaejasmine caused an increase of the G2/M phase population from $19.86 \%$ to $66.55 \%$, as compared to $16.61 \%$ of G2/M phase cells in untreated control samples $(p<0.05)$. Hence, chamaejasmine exerted growth-inhibitory effects via $\mathrm{G} 2 / \mathrm{M}$ phase arrest in a concentration-dependent manner.

The annexin V-FITC apoptosis detection kit was then employed to examine the influence of chamaejasmine on MDA-MB-231 cells apoptosis by flow cytometry. As shown in Figure 3, only a few untreated MDA-MB-231 (1.64\%) cells bounded annexin V-FITC. Whereas, MDA-MB-231 cells binded annexin V-FITC highly increased in a concentration-dependent manner after treatment with 4-16 $\mu \mathrm{M}$ chamaejasmine $(13.06 \%$ to $78.05 \%, p<0.05)$. To sum up, dots were dispersed and shifted to the Q2 side in a dose-dependent manner when MDA-MB-231 cells were treated with chamaejasmine, indicating that the cells moved to the late apoptotic stage. These experimental results demonstrate that chamaejasmine induced apoptosis of MDA-MB-231 cells. 
Figure 2. Cell cycle distribution of MDA-MB-231 cells after treatment with different concentrations of chamaejasmine for $48 \mathrm{~h}$. (A), treatment with $0 \mu \mathrm{M}$ chamaejasmine; (B), treatment with $4 \mu \mathrm{M}$ chamaejasmine; (C), treatment with $8 \mu \mathrm{M}$ chamaejasmine; (D), treatment with $16 \mu \mathrm{M}$ chamaejasmine. Blue $=\mathrm{G} 1$; red $=\mathrm{S}$; green $=\mathrm{G} 2 / \mathrm{M}$. The figure shown here are representative of three independent experiments with similar results.
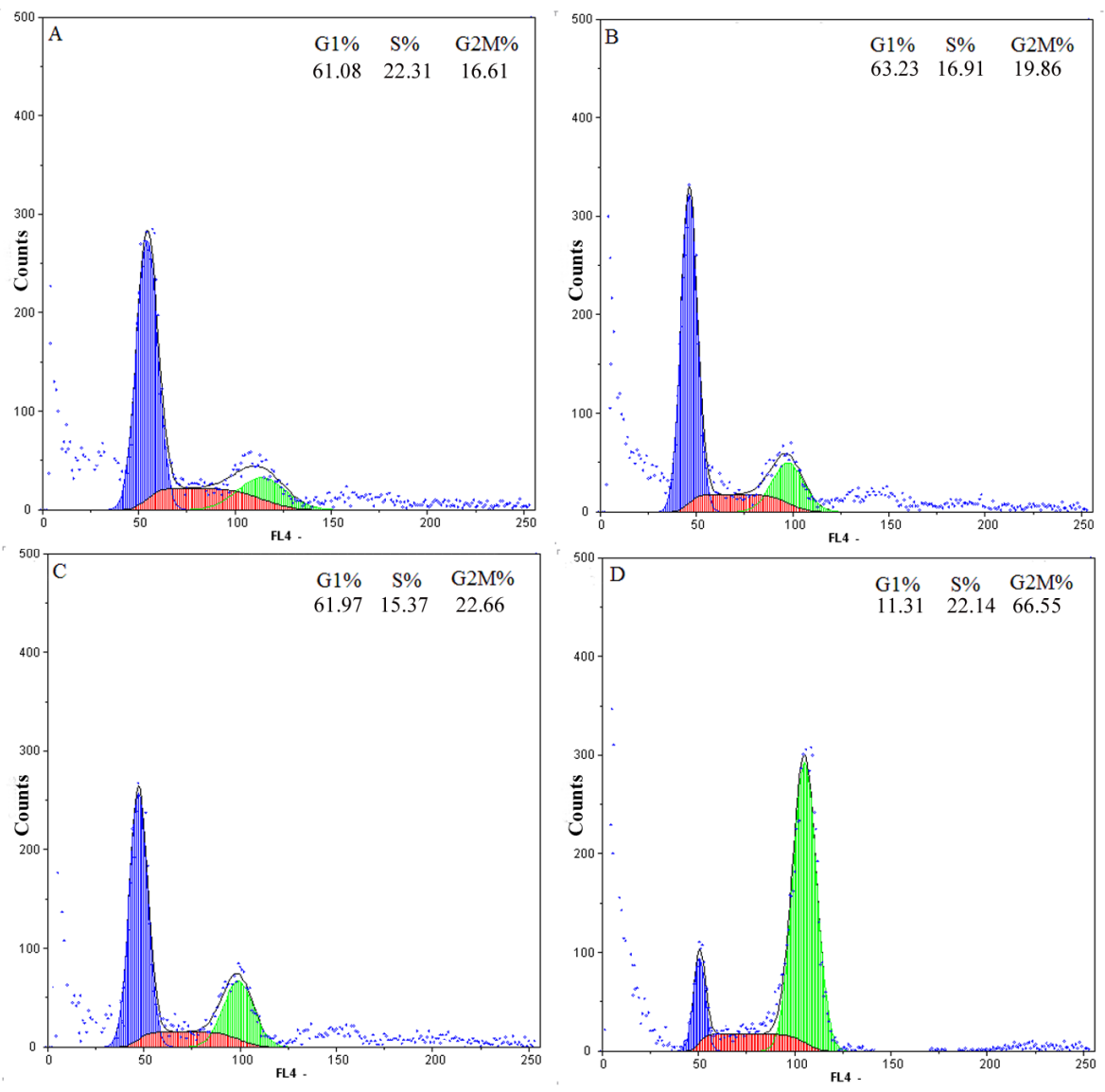

2.3. Inhibition of Cyclins, Cdk2, cdc2 and Induction of WAF1/p21 and KIP1/p27 by Chamaejasmine in MDA-MB-231 Cells

Many reports have revealed that cell cycle regulators are frequently mutated in most common malignancies [21,22]. Thus, we examined the effects of chamaejasmine on cell cycle inhibitory proteins KIP1/p27 and WAF1/p21, which are involved in cell cycle progression. Western blotting analysis showed a significant induction of these proteins in a dose-dependent manner (Figure 4A). The effects of chamaejasmine on the proteins levels of cyclins, cdk2 and cdc2 (which are known to be regulated by KIP1/p27 and WAF1/p21) were next evaluated. Chamaejasmine treatment of cells resulted in a significant dose-dependent decrease in the protein levels of cyclin A and B1 as well as $\operatorname{cdk} 2$ and cdc2 (Figure 4B,C). These results suggested that chamaejasmine restored proper checkpoint control via modulation of the cyclins, cdk2, cdc2 and the expression of their inhibitors. 
Figure 3. Chamaejasmine induced apoptosis in MDA-MB-231 cells using annexin V-FITC/PI. (a) Treatment with $0 \mu \mathrm{M}$ chamaejasmine; (b) treatment with $4 \mu \mathrm{M}$ chamaejasmine; (c) treatment with $8 \mu \mathrm{M}$ chamaejasmine; (d) treatment with $16 \mu \mathrm{M}$ chamaejasmine.

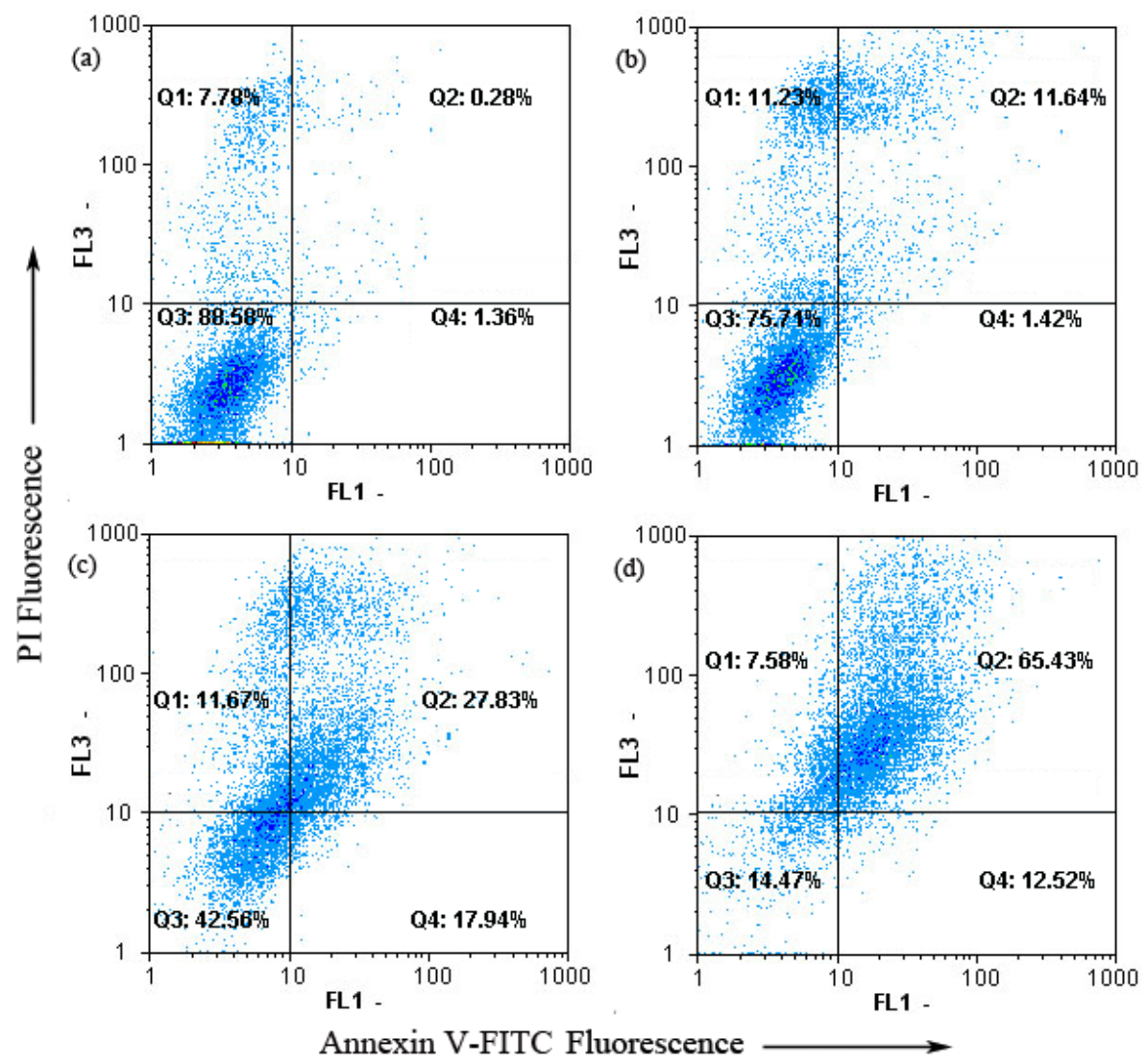

Figure 4. (A) Effects of chamaejasmine on protein expression of WAF1/p21 and KIP1/p27 in MDA-MB-231 cells. (B) Effects of chamaejasmine on protein expression of cyclin A and cyclin B1 in MDA-MB-231 cells. (C) Effects of chamaejasmine on protein expression of cdk2 and cdc2 in MDA-MB-231 cells. As detailed in Materials and Methods, the cells were treated with chamaejasmine $(4-16 \mu \mathrm{M})$ and then harvested. Total cell lysates were prepared and $20 \mu \mathrm{g}$ proteins were subjected to SDS-PAGE followed by western blotting analysis. Equal loading of proteins was confirmed by stripping the western blotting and reprobing it for $\beta$-actin. The western blotting shown here are representative of three independent experiments with similar results. The values below the figures represent relative density of the bands normalized to $\beta$-actin.

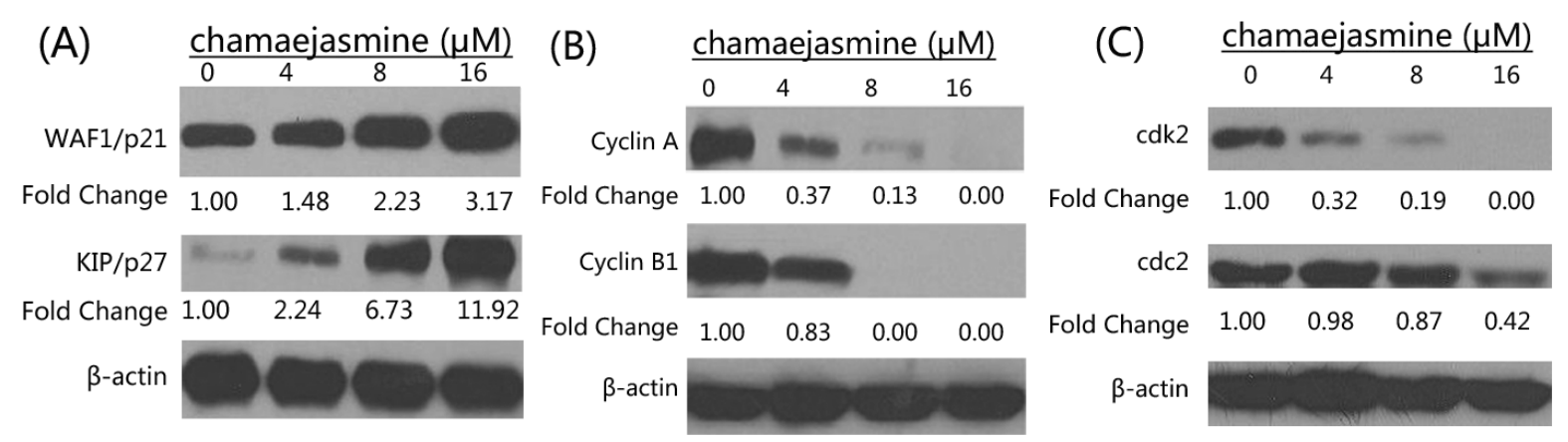




\subsection{Induction of Bax and Inhibition of Bcl-2 and Procaspases in MDA-MB-231 Cells}

In order to investigate the mechanism by which chamaejasmine induces apoptosis, the changes in the level of apoptosis-related proteins (Bax, Bcl-2, caspase-3 and caspase-8) were examined (Figure 5A,B). As shown in Figure 5A, western blotting analysis revealed a significant increase in the expression of Bax in chamaejasmine treated MDA-MB-231 cells, while there was a significant decrease in Bcl-2 expression, indicating that the $\mathrm{Bax} / \mathrm{Bcl}-2$ ratio increased significantly. Pro-caspase-3 levels decreased upon treatment with chamaejasmine, while the levels of active caspase- 3 increased. Similarly, pro-caspase- 8 levels decreased upon treatment with chamaejasmine which induced increase active caspase-8 (Figure 5B).

Figure 5. (A) Effects of chamaejasmine on proteins expression of Bax, Bcl-2 in MDAMB-231cells. (B) Effects of chamaejasmine on proteins expression of caspase-3 and -8 in MDA-MB-231 cells. (C) Effects of chamaejasmine on IKK $\alpha$, IKK $\beta$, phosphorylation IKB $\alpha$ as well as degradation of I $\mathrm{B} \alpha$ in MDA-MB-231 cells. (D) Effects of chamaejasmine on activation of NF- $\kappa B$ in MDA-MB-231 cells by western blotting analysis. As detailed in Materials and Methods, the cells were treated with chamaejasmine $(4-16 \mu \mathrm{M})$ and then harvested. Total cell lysates were prepared and $20 \mu \mathrm{g}$ proteins were subjected to SDS-PAGE followed by western blotting analysis. Equal loading of proteins was confirmed by stripping the western blot and reprobing it for $\beta$-actin. The western blots shown here are representative of three independent experiments with similar results. The values below the figures represent relative density of the bands normalized to $\beta$-actin.

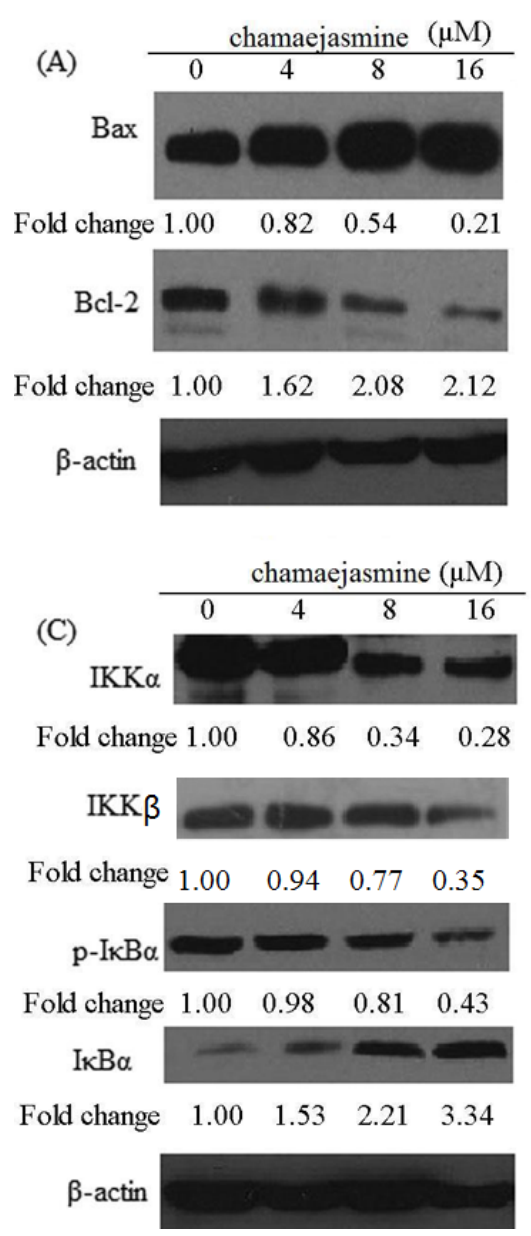

(B)

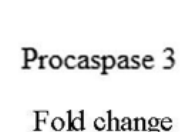

Active caspase 3

Fold change

Procaspase 8

Fold change

Active caspase 8

Fold change

$\beta$-actin

(D)
$\mathrm{NF}-\mathrm{\kappa B} / \mathrm{p} 65$
(nuclear)
Fold change

Fold change

Lamin

$\mathrm{p}-\mathrm{NF}-\kappa \mathrm{B}$

(Ser536)

Fold change

$\beta$-actin
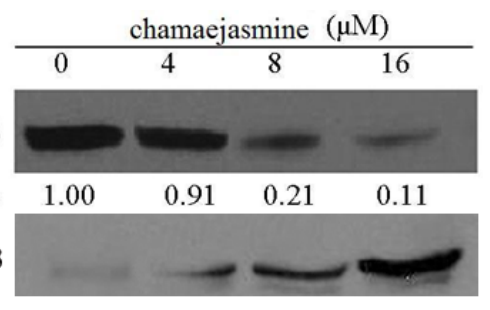

$\begin{array}{llll}1.00 & 1.78 & 2.36 & 4.28\end{array}$
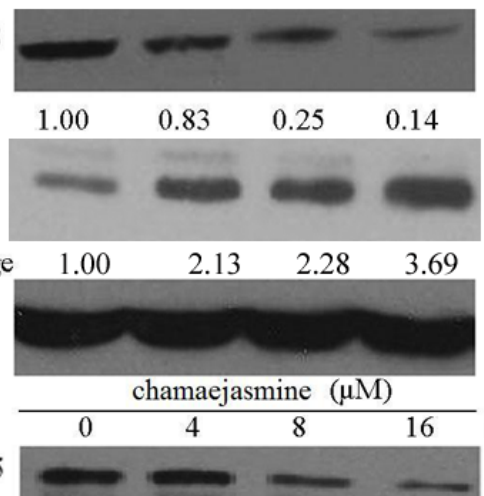

$\begin{array}{llll}1.00 & 0.92 & 0.41 & 0.19\end{array}$
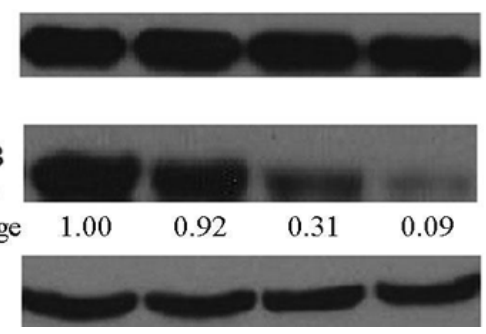


\subsection{Inhibition of NF- $\kappa B$ Pathway by chamaejasmine in MDA-MB-231 Cells}

Treatment of MDA-MB-231 cells with chamaejasmine $(4-16 \mu \mathrm{M})$ resulted in a significant inhibition in the phosphorylation of $\mathrm{I} \kappa \mathrm{B} \alpha$ protein (Figure $5 \mathrm{C}$ ). To evaluate the possible inhibitory mechanism of chamaejasmine on I $\mathrm{BB} \alpha$ protein increase, IKK $\alpha$ and IKK $\beta$ protein level was then measured. Western blotting analysis showed that pre-treatment of MDA-MB-231 cells with chamaejasmine inhibited IKK $\alpha$ and IKK $\beta$ in a dose-dependent manner (Figure 5C). Furthermore, chamaejasmine treatment cells resulted in decreased phospho-NF- $\mathrm{BB} / \mathrm{p} 65$ at Ser536 and inhibition of translocation of NF- $\kappa \mathrm{B} / \mathrm{p} 65$ in the nuclear fraction (Figures $5 \mathrm{D}$ and 6 ).

Figure 6. Immunofluorescence analysis of NF-kB (p65 subunit) localization in the nuclei of MDA-MB-231 cells after 0-16 $\mu \mathrm{M}$ chamaejasmine treatment. A repeat experiment gave very similar results.

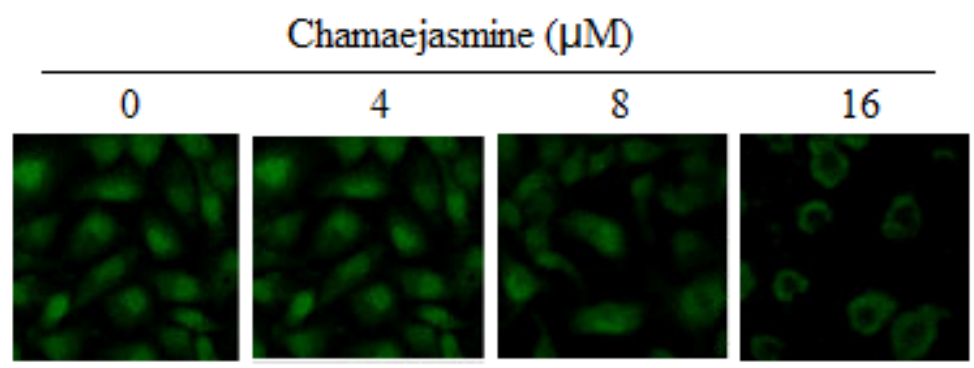

\section{Discussion}

Recently, the antitumor activity of constituents obtained from Stellerachamaejasme L. has become a research hotspot. For example, chamaejasmine showed notable anticancer activity against HEp-2, NCI-H1975, HT-29 and SKOV-3. MCF-7, A549, SGC-7901, HCT-8, HO-4980, Hela, HepG2, PC-3, LNCap, with the $\mathrm{IC}_{50}$ values of $1.92,3.61,14.30,10.67,8.04,4.02,4.84,11.97,12.45,5.31,9.88$, 14.36, 2.28 and 5.21 $\mu \mathrm{M}$ [23,24]. Furthermore, daphnoretin was found to obviously inhibit HOS, U2-OS and MG-63, with the $\mathrm{IC}_{50}$ values of 3.89, 8.72 and 5.11 $\mu \mathrm{M}$ [25]. Besides, chamaejasmine exhibited strong inhibition against all three human breast cancer cell lines (HCC1937, MDA-MB-453 and MDA-MB-231). Based on all above, it seemed that the presence of hydroxyl group may contribute to the obvious anticancer activity of chamaejasmine. The antitumor activity of biflavanones or their structural derivatives need to be further evaluated in cancer cell lines.

Several studies have shown that the induction of apoptosis might be due to cell cycle arrest [26,27]. Cell cycle control is a major regulatory mechanism of cell growth [28]. Blockade of the cell cycle is considered as an effective strategy for the development of novel cancer therapies [29,30]. Cell cycle analysis of the treated culture revealed that chamaejasmine induced a concentration-dependent G2/M phase cell cycle arrest with an accompaniment decrease in G1 and S phase.

It is known that cell cycle is primarily regulated by complexes containing cdks and cyclins, which are critical for the progression of cell cycle and whose inactivation leads to cell cycle arrest $[31,32]$. Cdk activity is additionally regulated by cdk inhibitors such as the WAF1/p21 and KIP1/p27 proteins families. Among Cdks that regulate cell cycle progression, $\mathrm{Cdk} 2$ and $\mathrm{Cdc} 2$ kinases are primarily activated in association with cyclin A and cyclin B1 during the progression of the G2/M phase $[33,34]$. Thus, 
our data suggest that cell cycle arrest at the G2/M phase is mediated by reduction of cyclin $\mathrm{A}$ and cdc2/cyclin B complex formation, which is an essential step in regulating the cells passage into mitosis. It could be conclude the cell cycle arrest may partly explain apoptosis and anti-proliferative effects induced by chamaejasmine.

Bcl-2, an upstream effect or molecule in the apoptotic pathway, has been identified as a potent suppressor of apoptosis [35]. It has been proven that most cancers, including lung cancer, generally overexpress Bcl-2, thereby escaping apoptosis and undermining therapy. Bcl-2 forms a heterodimer with the apoptotic protein Bax and thereby neutralizes its apoptotic effect. Therefore, alteration in the ratio of $\mathrm{Bax} / \mathrm{Bcl} 2$ is a decisive factor that plays an important role to determine whether cells will undergo apoptosis [36,37]. Based on the above results, chamaejasmine significantly down-regulated Bcl-2 protein and up-regulated levels of Bax protein in MDA-MB-231 cells, suggesting the involvement of an intrinsic apoptotic pathway by which chamaejasmine induces apoptosis in MDA-MB-231 cells.

Caspases are part of a growing family of cysteine proteases which have been involved in many forms of apoptosis [38-40]. Activation of caspase proteases was required for the induction of apoptosis in different cell types [41,42]. Caspases include initiator caspases and effector caspases. Once the initiator caspases (caspases 8, 9, and 10, etc) are activated through intrinsic or extrinsic pathway, they are proteolytically cleaved and thus activate the effector caspases (caspases 3, 6, and 7, etc.) whose functions are known to be responsible for the cleavage of the intracellular substrates that leads to cell death. Caspase 3 is one of the key executioners of apoptosis. Upon activation, caspase 3 can cleave 5 substrates, including other effector caspases and fodrin, which form a cytoskeletal network [43]. The activated caspase- 3 and caspase- 8 detected in the results further explained the signaling pathway of chamaejasmine-induced apoptosis in MDA-MB-231 cells.

Activation of NF- $\kappa \mathrm{B}$ has been confirmed to block apoptosis and promote cell proliferation, and its increased activity is positively associated with many cancer types, including breast cancer [44]. Inhibition of tumorigenesis often involves modulation of signal transduction pathways, leading to cell cycle arrest and apoptosis. NF- $\mathrm{KB}$ is sequestered in the cytoplasm in an inactive form through interaction with $\mathrm{I} \kappa \mathrm{B}$. Phosphorylation of $\mathrm{I} \kappa \mathrm{B}$ by $\mathrm{I} \kappa \mathrm{B}$ kinase (IKK) causes ubiquitination and degradation of $I \kappa B$, thus releasing NF- $\kappa B$, which then translocates to the nucleus. Then it binds to specific B binding sites in the promoter regions of several genes [45]. Our results showed that treatment of chamaejasmine in MDA-MB-231 cells significantly inhibited IKK $\alpha$ and IKK $\beta$ as well as phosphorylation and degradation of $\mathrm{I} \kappa \mathrm{B} \alpha$ protein. This suggested that the effects of chamaejasmine on $\mathrm{NF}-\kappa \mathrm{B} / \mathrm{p} 65$ are through inhibition of phosphorylation and subsequent proteolysis of $\mathrm{I} \kappa \mathrm{B} \alpha . \mathrm{NF}-\kappa \mathrm{B}$ is a ubiquitous transcription factor that controls the expression of genes involved in immune responses, apoptosis, and cell cycle. It has been shown to modulate the expression of cyclin B1 [46,47]. Moreover, NF- $\mathrm{KB}$ plays important role in p53-mediated apoptosis. P53 can induce activation of NF-kB, and loss of NF-kB activity specially abrogated the p53-mediated apoptotic response, without impinging on the ability to activate expression of target genes or induce cell-cycle arrest [48]. 


\section{Experimental}

\subsection{Materials}

Bax, Bcl-2, I $\mathrm{B} \alpha$, I $\kappa \mathrm{B} \alpha$ (phospho), anticyclinA, B1, cdk2, cdc2, WAF1/p21and KIP1/p27, $p$-NF- $\kappa \mathrm{B} / \mathrm{p} 65$ antibodies were obtained from Cell Signaling Technology (Beverly, MA, USA). The mono and polyclonal antibodies IKK $\alpha$, IKK $\beta$, Procaspase 3, 8 and NF- $\kappa \mathrm{B} / \mathrm{p} 65$ were obtained from Santa Cruz Biotechnology Inc. (Santa Cruz, CA, USA). Anti-mouse and anti-rabbit secondary antibody alkaline phosphatase peroxidase conjugate was obtained from Amersham Life Science Inc. (Arlington Height, IL, USA). BCA Protein assay kit was obtained from Pierce (Rockford, IL, USA). Novex precast Tris-glycine gels were obtained from Invitrogen (Carlsbad, CA, USA). The Apo-Direct kit for flow cytometry was purchased from Phoenix Flow Systems (San Diego, CA, USA).

\subsection{Cell Culture and Chemicals}

Three human breast cancer cell lines (HCC1937, MDA-MB-453 and MDA-MB-231) were obtained from The Cell Bank of Type Culture Collection of Chinese Academy of Sciences, Shanghai Institute of Cell Biology, Chinese Academy of Sciences (Shanghai, China). HCC1937 was maintained in RPMI-1640 (Invitrogen Life Technologies, Carlsbad, CA, USA), and MDA-MB-453 and MDA-MB-231 was maintained in L-15 (Invitrogen Life Technologies, Carlsbad, CA, USA). The medium were supplemented with 10\% fetal bovine serum (FBS, Gibco, Carlsbad, CA, USA), $100 \mathrm{U} / \mathrm{mL}$ penicillin and $100 \mu \mathrm{g} / \mathrm{mL}$ streptomycin at $37{ }^{\circ} \mathrm{C}$ and $5 \% \mathrm{CO}_{2}$. Chamaejasmine (purity $\geq 99 \%$, molecular weight: 542.49) were obtained from National Research Center for Certified Reference Materials (Beijing, China). Apigenin (purity $\geq 99 \%$, molecular weight: 270.25) were obtained from Sigma Chemical Co. (St. Louis, MO, USA). A $10 \mathrm{mM}$ stock solution of chamaejasmine was prepared in dimethyl sulfoxide (DMSO) and stored at $-80^{\circ} \mathrm{C}$. MTT was also obtained from Sigma-Aldrich Inc. Deionized water was used in all experiments.

\subsection{Cytotoxicity Assay}

Inhibition of cell proliferation of chamaejasmine was measured by the MTT assay [49]. Briefly, cells were plated in 96-well culture plates $\left(1 \times 10^{5}\right.$ cells/well $)$ separately. After $24 \mathrm{~h}$ incubation, cells were treated with chamaejasmine or apigenin $(1,2,4,8,16,32$ and $64 \mu \mathrm{M}$, eight wells per concentration) for $72 \mathrm{~h}$, MTT solution $(5 \mathrm{mg} / \mathrm{mL})$ was then added to each well. After $4 \mathrm{~h}$ incubation, the formazan precipitate was dissolved in dimethyl sulfoxide $(100 \mu \mathrm{L})$ and then the absorbance was measured in an ELISA reader (Thermo Molecular Devices Co., Union City, CA, USA) at $570 \mathrm{~nm}$. The cell viability ratio was calculated by the following formula: Inhibitory ratio $(\%)=\left[\left(\mathrm{OD}_{\text {control }}-\mathrm{OD}_{\text {treated }}\right) /\left(\mathrm{OD}_{\text {control }}\right)\right] \times 100 \%$. Cytotoxicity was expressed as the concentration of chamaejasmine inhibiting cell growth by $50 \%$ ( $\mathrm{IC}_{50}$ value).

\subsection{Flow Cytometric Analysis of Cell Cycle and Apoptosis}

Cell cycle was studied with CyStain (Partec GmbH, Görlitz, Germany) [49]. Briefly, $1 \times 10^{6}$ cells/well MDA-MB-231 cells were seeded in six-well plate and left for $24 \mathrm{~h}$ in incubator to resume exponential 
growth. Cells were exposed to chamaejasmine $(0,4,8$ and $16 \mu \mathrm{M})$ and incubated for $48 \mathrm{~h}$. Then, the cells were harvested and washed with PBS. After suspension in PBS $(800 \mu \mathrm{L})$ and CyStain $(200 \mu \mathrm{L})$ the cell cycle distribution of 10,000 cells was recorded by flow cytometry (Partec), and the percentage of cells at G0/G1, S, and G2/M phases was analyzed using the FloMax software (Partec).

The extent of apoptosis was measured through annexinV-FITC apoptosis detection kit (Beyotime Institute of Biotechnology, Jiangsu, China) as described by the manufacture's instruction [49]. After exposure to chamaejasmine $(0,4,8$ and $16 \mu \mathrm{M})$ for $48 \mathrm{~h}$, cells were collected, washed twice with PBS, gently resuspended in annexinV binding buffer and incubated with annexinV-FITC/PI in dark for 15 min and analyzed by flow cytometry using FloMax software. The fraction of cell population in different quadrants was analyzed using quadrant statistics. The lower left quadrant contained intact cells; lower right quadrant apoptotic and in the upper right quadrant necrotic or post-apoptotic cells.

\subsection{Preparation of Cytosolic and Nuclear Lysates}

Following treatment of cells with chamaejasmine $(0,4,8$ and $16 \mu \mathrm{M}, 48 \mathrm{~h})$, the medium was aspirated, and the cells were washed twice with PBS (10 mM, pH 7.4). The cells were incubated in $0.2 \mathrm{~mL}$ ice-cold lysis buffer (HEPES (10 mM, pH 7.9), $\mathrm{KCl}(10 \mathrm{mM})$, EDTA $(0.1 \mathrm{mM})$, EGTA (0.1 mM), DTT $(1 \mathrm{mM})$, PMSF $(1 \mathrm{mM})$ with freshly added protease inhibitor cocktail (Protease Inhibitor Cocktail Set III; Calbiochem, La Jolla, CA, USA) for $15 \mathrm{~min}$, after which $12.5 \mu \mathrm{L}$ of $10 \%$ Nonidet P-40 was added and the contents were mixed on a vortex and then centrifuged for $1 \mathrm{~min}(14,000 \mathrm{~g})$ at $4{ }^{\circ} \mathrm{C}$. The supernatant was saved as cytosolic lysate and stored at $-80{ }^{\circ} \mathrm{C}$. The nuclear pellet was resuspended in $50 \mu \mathrm{L}$ of ice-cold nuclear extraction buffer [HEPES (20 mM, pH 7.9), $\mathrm{NaCl}(0.4 \mathrm{M})$, EDTA $(1 \mathrm{mM})$, EGTA $(1 \mathrm{mM})$, DTT $(1 \mathrm{mM})$, PMSF $(1 \mathrm{mM})]$ with freshly added protease inhibitor cocktail (Protease Inhibitor Cocktail Set III; Calbiochem) for $30 \mathrm{~min}$ with intermittent mixing. The tubes were centrifuged for $5 \mathrm{~min}(14,000 \mathrm{~g})$ at $4{ }^{\circ} \mathrm{C}$, and the supernatant (nuclear extract) was stored at $-80{ }^{\circ} \mathrm{C}$.

\subsection{Western Blotting Assay}

To evaluate the expression levels of various intracellular proteins related to apoptosis, MDA-MB-231 cells were treated with chamaejasmine $(0,4,8$ and $16 \mu \mathrm{M})$ for $48 \mathrm{~h}$, respectively. For isolation of total protein fractions, cells were collected, washed twice with ice-cold PBS, and lysed using cell lysis buffer [20 mMTris pH 7.5, $150 \mathrm{mMNaCl}, 1 \%$ Triton $\mathrm{X}-100,2.5 \mathrm{mM}$ sodium pyrophosphate, $1 \mathrm{mM}$ EDTA, $1 \% \mathrm{Na}_{2} \mathrm{CO}_{3}, 0.5 \mu \mathrm{g} / \mathrm{mL}$ leupeptin, $1 \mathrm{mM}$ phenylmethylsulfonyl fluoride (PMSF)]. The lysates were collected by scraping from the plates and then centrifuged at $10,000 \mathrm{rpm}$ at $4{ }^{\circ} \mathrm{C}$ for $5 \mathrm{~min}$. Total protein samples $(20 \mu \mathrm{g})$ were loaded on a $12 \%$ of SDS polyacrylamide gel for electrophoresis, and transferred onto PVDF transfer membranes (Millipore, Billerica, MA, USA) at $0.8 \mathrm{~mA} / \mathrm{cm}^{2}$ for $2 \mathrm{~h}$. Membranes were blocked at room temperature for $2 \mathrm{~h}$ with blocking solution (1\% BSA in PBS plus $0.05 \%$ Tween-20). Membranes were incubated overnight at $4{ }^{\circ} \mathrm{C}$ with primary antibodies at a $1: 1,000$ dilution in blocking solution. After thrice washings in TBST for each $5 \mathrm{~min}$, membranes were incubated for $1 \mathrm{~h}$ at room temperature with an alkaline phosphatase peroxidase conjugated anti-mouse secondary antibody at a dilution of 1:500 in blocking solution. Detection was performed by the BCIP/NBT 
Alkaline Phosphatase Color Development Kit (Beyotime Institute of Biotechnology) according to the manufacturer's instructions. Bands were recorded by a digital camera (Nikon, Tokyo, Japan).

\subsection{Immunofluorescence Assay}

The cells were grown at a density of $2 \times 10^{4} /$ well on 6 -well culture plates (Nunc Inc., Naperville, IL, USA). After the treatments, the cells were washed with PBS and fixed with cold methanol for 5 min at $-20{ }^{\circ} \mathrm{C}$. The cells were incubated with a 1:100 dilution of anti-p65 antibody, followed by probing with a 1:800 dilution of Alexa Fluor 488 - conjugated goat anti-rabbit IgG. The cells were examined with a Zeiss Axiovert 200M microscope, and data were analyzed using Carl Zeiss Axiovision software (Carl Zeiss Instruments, Jena, Germany).

\subsection{Statistical Analysis}

The data were expressed as mean \pm S.D. All statistics were calculated using the STATISTICA program (StatSoft, Tulsa, OK, USA). A $p$-value of $<0.05$ was considered as significant.

\section{Conclusions}

In summary, the present study showed that chamaejasmine inhibited the growth of MDA-MB-231 cells resulted from cell cycle arrest at G2/M phase, accompanied by cell apoptosis. Chamaejasmine induced cell cycle arrest through cyclinA, cyclinB1, cdk2 and cdc2 inhibition. These events were found to be associated with alterations in the levels of Bax, Bcl-2, caspase-8 and caspase-3. Our results further showed that the effects of chamaejasmine on $\mathrm{NF}-\mathrm{\kappa B} / \mathrm{p} 65$ are through inhibition of phosphorylation and subsequent proteolysis of $\mathrm{I} \kappa \mathrm{B} \alpha$. All these evidences provide a rationale to explore chamaejasmine as a preventive and perhaps as a chemotherapeutic agent in the management of breast cancer.

\section{Acknowledgments}

This wok was financially supported by the topic of Heilongiiang Provincial Health Bureau (No.682, No. 2012-625) and the topic of Heilongjiang Provincial Education Bureau (T. Zhang, H. Yu).

\section{References}

1. Mohinta, S.; Mohinta, H.; Chaurasia, P.; Watabe, K. Wnt pathway and breast cancer. Front. Biosci. 2007, 12, 4020-4033.

2. Desantis, C.; Siegel, R.; Bandi, P.; Jemal, A. Breast cancer statistics, 2011. CA Cancer J. Clin. 2011, 61, 409-418.

3. Mavrogenis, A.F.; Pala, E.; Romantini, M.; Guerra, G.; Romagnoli, C.; Maccauro, G.; Ruggieri, P. Side effects of radiation in musculoskeletal oncology: Clinical evaluation of radiationinduced fractures. Int. J. Immunopathol. Pharmacol. 2011, 24, 29-37.

4. Mavrogenis, A.F.; Papagelopoulos, P.J.; Romantini, M.; Angelini, A.; Ruggieri, P. Side effects of chemotherapy in musculoskeletal oncology. J. Long Term Eff. Med. Implants 2010, 20, 1-12.

5. Koo, N.K.; Kim, Y.C. A Case of Paclitaxel-induced Maculopathy Treated with Methazolamide. Korean J. Ophthalmol. 2012, 26, 394-397. 
6. Yim, D.; Singh, R.P.; Agarwal, C.; Lee, S.; Chi, H.; Agarwal, R. A Novel Anticancer Agent, Decursin, Induces G1 Arrest and Apoptosis in Human Prostate Carcinoma Cells. Cancer Res. 2005, 65, 1035-1044.

7. Tomasini, R.; Mak, T.W.; Melino, G. The impact of p53 and p73 on aneuploidy and cancer. Trends Cell Biol. 2008, 18, 244-252.

8. Vinatier, D.; Dufour, P.; Subtil, D. Apoptosis: A programmed cell death involved in ovarian and uterine physiology. Eur. J. Obstet. Gyn. R. B. 1996, 67, 85-102.

9. Das, G.C.; Holiday, D.; Gallardo, R.; Haas, C. Taxol-induced cell cycle arrest and apoptosis: Dose-response relationship in lung cancer cells of different wild-type p53 status and under isogenic condition. Cancer Lett. 2001, 165, 147-153.

10. Debatin, K.-M. Activation of apoptosis pathways by anticancer treatment. Toxicol. Lett. 2000, 112, 41-48.

11. Da Silva, C.P.; de Oliveira, C.R.; de Lima, M.C.P. Apoptosis as a mechanism of cell death induced by different chemotherapeutic drugs in human leukemic T-lymphocytes. Biochem. Pharmacol. 1996, 51, 1331-1340.

12. Sarraf, C.E.; Bowen, I.D. Proportions of Mitotic and Apoptotic Cells In A Range of Untreated Experimental Tumours. Cell Prolif. 1988, 21, 45-49.

13. Carson, D.A.; Ribeiro, J.M. Apoptosis and disease. Lancet 1993, 341, 1251-1254.

14. Newman, D.J.; Cragg, G.M.; Snader, K.M. Natural Products as Sources of New Drugs over the Period 1981-2002. J. Nat. Prod. 2003, 66, 1022-1037.

15. Cragg, G.M.; Newman, D.J. Plants as a source of anti-cancer agents. J. Ethnopharmacol. 2005, 100, 72-79.

16. Shi, Z.C. The Poisonous Plants in Chinese Pasture; China Agricultural Press: Beijing, China, 1997.

17. Zhao, S.H.; Wan, S.Q. Progress of investigations and application of insecticide plants. Guangdong Agric. Sci. 1997, 1, 26-28.

18. Feng, W.; Tetsuro, I.; Mitsuzi, Y. The antitumor activities of gnidimacrin isolated from Stellera chamaejasme L. Zhonghua Zhong Liu Za Zhi 1996, 8, 101-104.

19. Jin, C.; Michetich, R.G.; Daneshtalab, M. Flavonoids from Stellera chamaejasme. Phytochemistry 1999, 50, 505-508.

20. Yang, G.; Chen, D. Biflavanones, Flavonoids, and Coumarins from the Roots of Stellera chamaejasme and Their Antiviral Effect on Hepatitis B Virus. Chem. Biodivers. 2008, 5, 1419-1424.

21. Malumbres, M.; Barbacid, M. Cell cycle, CDKs and cancer: A changing paradigm. Nat. Rev. Cancer 2009, 9, 153-166.

22. Herman, J.G.; Merlo, A.; Mao, L.; Lapidus, R.G.; Issa, J.P.; Davidson, N.E.; Sidransky, D.; Baylin, S.B. Inactivation of the CDKN2/p16/MTS1 Gene Is Frequently Associated with Aberrant DNA Methylation in All Common Human Cancers. Cancer Res. 1995, 55, 4525-4530.

23. Wang, Y.; Zhao, Y.; Liu, Y.; Tian, L.; Jin, D. Chamaejasmine Inactivates Akt To Trigger Apoptosis in Human HEp-2 Larynx Carcinoma Cells. Molecules 2011, 16, 8152-8164.

24. Fang, W.; Liu, S.; Nie, Y. Anticancer Activity of Chamaejasmine: Effect on Tubulin Protein. Molecules 2011, 16, 6243-6254.

25. Gu, S.; He, J. Daphnoretin Induces Cell Cycle Arrest and Apoptosis in Human Osteosarcoma (HOS) Cells. Molecules 2012, 17, 598-612. 
26. Hartwell, L.H.; Kastan, M.B. Cell cycle control and cancer. Science 1994, 266, 1821-1828.

27. Vermeulen, K.; van Bockstaele, D.R.; Berneman, Z.N. The cell cycle: A review of regulation, deregulation and therapeutic targets in cancer. Cell Prolif. 2003, 36, 131-149.

28. Jeong, H.-W.; Han, D.C.; Son, K.-H.; Han, M.Y.; Lim, J.S.; Ha, J.H.; Lee, C.W.; Kim, H.M.; Kim, H.C.; Kwon, B.M. Antitumor effect of the cinnamaldehyde derivative CB403 through the arrest of cell cycle progression in the G2/M phase. Biochem. Pharmacol. 2003, 65, 1343-1350.

29. Buolamwini, J.K. Cell Cycle Molecular Targets in Novel Anticancer Drug Discovery. Curr. Pharm. Des. 2000, 14, 379-392.

30. McDonald, E.R., III; El-Deiry, W.S. Cell cycle control as a basis for cancer drug development. Int. J. Oncol. 2000, 16, 871-957.

31. Devault, A.C.J.; Fesquet, D.; Labbé, J.C.; Lorca, T.; Picard, A.; Strausfeld, U.; Dorée, M. Concerted roles of cyclin $\mathrm{A}$, cdc25+ mitotic inducer, and type $2 \mathrm{~A}$ phosphatase in activating the cyclin B/cdc2 protein kinase at the G2/M phase transition. Cold Spring Harb. Symp. Quant. Biol. 1991, 56, 503-513.

32. Van den Heuvel, S.; Harlow, E. Distinct roles for cyclin-dependent kinases in cell cycle control. Science 1993, 262, 2050-2054.

33. Nurse, P. Universal control mechanism regulating onset of M-phase. Nature 1990, 344, 503-508.

34. Piao, W.; Yoo, J.; Lee, K.D.; Hwang, H.J.; Kim, J.H. Induction of G2/M phase arrest and apoptosis by a new synthetic anti-cancer agent, DW2282, in promyelocytic leukemia (HL-60) cells. Biochem. Pharmacol. 2001, 62, 1439-1447.

35. Hockenbery, D.M.; Oltvai, Z.N.; Yin, X.-M.; Milliman, C.L.; Korsmeyer, S.J. Bcl-2 functions in an antioxidant pathway to prevent apoptosis. Cell 1993, 75, 241-251.

36. Reed, J.C. Regulation of apoptosis by bcl-2 family proteins and its role in cancer and chemoresistance. Curr. Opin. Oncol. 1995, 7, 541-546.

37. Revelos, K.; Petraki, C.; Gregorakis, A.; Scorilas, A.; Papanastasiou, P.; Koutsilieris, M. Immunohistochemical Expression of $\mathrm{Bcl} 2$ is an Independent Predictor of Time-to-biochemical Failure in Patients with Clinically Localized Prostate Cancer Following Radical Prostatectomy. Anticancer Res. 2005, 25, 3123-3133.

38. Nicholson, D.W. Caspase structure, proteolytic substrates, and function during apoptotic cell death. Cell Death Differ. 1999, 6, 1028-1042.

39. Grutter, M.G. Caspases: Key players in programmed cell death. Curr. Opin. Struct. Biol. 2000, 10, 649-655.

40. Zimmermann, K.C.; Bonzon, C.; Green, D.R. The machinery of programmed cell death. Pharmacol. Ther. 2001, 92, 57-70.

41. Islam, S.; Islam, N.; Kermode, T.; Johnstone, B.; Mukhtar, H.; Moskowitz, R.W.; Goldberg, V.M.; Malemud, C.J.; Haqqi, T.M. Involvement of Caspase-3 in Epigallocatechin-3-gallate-Mediated Apoptosis of Human Chondrosarcoma Cells. Biochem. Biophys. Res. Commun. 2000, 270, 793-797.

42. Hayakawa, S.; Saeki, K.; Sazuka, M.; Suzuki, Y; Shoji, Y.; Ohta, T.; Kaji, K.; Yuo, A.; Isemura, M. Apoptosis Induction by Epigallocatechin Gallate Involves Its Binding to Fas. Biochem. Biophys. Res. Commun. 2001, 285, 1102-1106. 
43. Hsu, H.-F.; Houng, J.-Y.; Kuo, C.-F.; Tsao, N.; Wu, Y.-C. Glossogin, a novel phenylpropanoid from Glossogyne tenuifolia, induced apoptosis in A549 lung cancer cells. Food Chem. Toxicol. 2008, 46, 3785-3791.

44. Lee, J.; Im, Y.-H.; Jung, H.H.; Kim, J.H.; Park, J.O.; Kim, K.; Kim, W.S.; Ahn, J.S.; Jung, C.W.; Park, Y.S.; et al. Curcumin inhibits interferon- $\alpha$ induced NF- $\kappa \mathrm{B}$ and COX-2 in human A549 non-small cell lung cancer cells. Biochem. Biophys. Res. Commum. 2005, 334, 313-318.

45. Gupta, S.; Hastak, K.; Afaq, F.; Ahmad, N.; Mukhtar, H. Essential role of caspases in epigallocatechin-3-gallate-mediated inhibition of nuclear factor kappaB and induction of apoptosis. Oncogene 2004, 23, 2507-2522.

46. Thati, B.; Noble, A.; Creaven, B.S.; Walsh, M.; McCann, M.; Devereux, M.; Kavanagh, K.; Egan, D.A. Role of cell cycle events and apoptosis in mediating the anti-cancer activity of a silver(I) complex of 4-hydroxy-3-nitro-coumarin-bis(phenanthroline) in human malignant cancer cells. Eur. J. Pharmacol. 2009, 602, 203-214.

47. Cude, K.; Wang, Y.; Choi, H.J.; Hsuan, S.L.; Zhang, H.; Wang, C.Y.; Xia, Z. Regulation of the G2-M cell cycle progression by the ERK5-NFjB signaling pathway. J. Cell Biol. 2007, 177, 253-264.

48. Curry, C.L.; Reed, L.L.; Broude, E.; Golde, T.E.; Miele, L.; Foreman, K.E. Notch inhibition in Kaposi's sarcoma tumor cells leads to mitotic catastrophe through nuclear factor-jB signaling. Mol. Cancer Ther. 2007, 6, 1983-1992.

49. Ryan, K.M.; Ernst, M.K.; Rice, N.R.; Vousden, K.H. Role of NF-kB in p53-mediated programmed cell death. Nature 2000, 404, 892-897.

Sample Availability: Samples of the compounds are available from the authors.

(C) 2013 by the authors; licensee MDPI, Basel, Switzerland. This article is an open access article distributed under the terms and conditions of the Creative Commons Attribution license (http://creativecommons.org/licenses/by/3.0/). 